\title{
Disability factors among residents of old people's homes
}

\author{
T. C. TWINING AND D. G. ALLEN \\ From the Area Department of Clinical Psychology, Whitchurch Hospital, Whitchurch, Cardiff
}

SUMmaRY A standardised behaviour rating scale, the Shortened Stockton Rating Scale, was completed by care staff for each of 903 residents in old people's homes. In an attempt to validate the four subscales suggested by the authors of the published scale, the data were subjected to factor analysis. The results indicate the existence of three factors reflecting physical, mental, and social impairment. They offer only partial support for the published subscales and the need for such scales to be validated on the intended target population is discussed.

An increasing number of reports in recent years have studied levels of function among populations of elderly people in institutions. ${ }^{1-4}$ Many of these have used the Stockton Geriatric Rating Scale ${ }^{5}$ and, particularly, its derivative, the Shortened Stockton Rating Scale (SSRS). ${ }^{1}$ The latter is currently incorporated in a published package of assessment measures. ${ }^{6}$ In this study we examine the factorial structure of the SSRS in a population of residents in homes for the elderly.

THE SHORTENED STOCKTON RATING SCALE The original Stockton Rating Scale was produced by Meer and Baker ${ }^{5}$ as a result of studies on geriatric subjects in the United States of America. Factor analysis of these data yielded four subscales, labelled physical disability, apathy, communications failure, and socially irritating behaviour. The shortened version (SSRS) was produced by Gilleard and Pattie ${ }^{1}$ on the basis of reliability studies of the Stockton scale on British populations. It features 18 of the most reliable items from the original scale, some with amended wording following Anglo-American translation. These are assigned to a subscale on the basis of the loading found by Meer and Baker ${ }^{5}$ for the corresponding item on the Stockton scale.

Subsequent factor analyses ${ }^{7}$ are reported to have confirmed at least three of these dimensions, although the published manual $^{6}$ contains no details of such analyses.

Masterton et $\mathrm{al}^{4}$ state that 'the high correlations between the sub-scores and the total score of the Stockton scales make it possible to obtain a detailed profile of behavioural assets and deficiencies which is a valid measure for comparing between and within groups'. Such high correlations suggest to the present authors, however, that the subscale scores may not be as independent as might originally have been supposed. In particular, any attempts to draw inferences relating to individual clinical assessments on the basis of subscale scores may be misleading if it is assumed that the subscales reflect independent underlying variables.

\section{Method}

In order to assess future planning needs, a survey was conducted between October 1979 and May 1980 to examine levels of disability among residents in homes for the elderly in South Glamorgan. The sample consisted of 903 subjects (615 women, 288 men) resident in 27 local authority homes. The county has a total provision of 970 beds; the reasons for the difference between the two totals are that a number of residents were in hospital when the data were collected and the care staffs had insufficient knowledge of certain other residents (for example, the 'short-stays') to enable them to complete the scales. Information was obtained on each resident using the published SSRS with one modification and seven additional items. The alteration was to split question 1 (see Appendix) into two separate items, one referring to 'bathing', the other to 'dressing'. This was done because, after consultations with nursing staff, it was felt unsatisfactory to combine the ratings of these two activities. For the purpose of the present analysis, these have been combined by taking each resident's higher score on the two items and excluding the additional items. 
The ratings were completed by care staff who, it was felt, had an intimate knowledge of the residents' behaviour through their close working relationship with them. Staff in each home were instructed in the use of the rating scale by a member of the research team and the ratings were generally collected over the course of a two-week period. This gave the care staff time to make particular observations of their allocated residents. Additional information was collected on $18 \%$ of the residents using a semistructured questionnaire which incorporated a screening test for dementia; the results of these analyses will be reported in a later paper.

\section{DATA ANALYSIS}

The SPSS computer programme ${ }^{8}$ was used to create two random samples which were then separately analysed using the principal components analysis with iteration rotated to a 'varimax' solution. This provided an opportunity to check the stability of factors. The samples (one containing 451 subjects, the other 475) were both taken from the whole population and are therefore overlapping. In both cases, the number of subjects is well in excess of the minimum number recommended by Everitt. ${ }^{\circ}$

\section{Results}

The two factor analyses differed in the total number of factors produced, as well as in their content, from the subscales in the published data (see Table 1).

It can be seen that the first two factors account for $88.9 \%$ and $81.3 \%$ of the variance in the first and second analyses respectively (Table 2 ).

The fourth factor appears only in sample II, when it has only a low eigen value of $0 \cdot 54$. Only factors $A$ and $B$ have an eigen value greater than 1 in both analyses, with factor $\mathrm{C}$ having an eigen value greater than 1 in analysis II only. Taking items as belonging to the factor on which they have their highest significant loading, the three principal factors appear to be:

$\begin{array}{ll}\begin{array}{l}\text { Bathing/Dressing } \\ \text { Walking }\end{array} & \begin{array}{c}\multicolumn{1}{c}{\boldsymbol{B}} \\ \text { Confusion } \\ \text { Appearance }\end{array} \\ \begin{array}{ll}\text { Incontinence } & \text { Sociability } \\ \text { Supervision needed Co-operation } \\ \text { outside home }\end{array} \\ \begin{array}{l}\text { Helps out in home } \\ \text { Engages in useful } \\ \text { activities }\end{array} & \begin{array}{l}\text { Comprehension } \\ \text { Communication }\end{array} \\ \end{array}$

$\stackrel{C}{\text { Objectionable (day) }}$

Objectionable (night)

Wrongly accuses others

Hoards meaningless items

Table 1 Varimax rotated factor matrices

\begin{tabular}{|c|c|c|c|c|c|c|c|c|c|}
\hline \multirow{3}{*}{$\begin{array}{l}\text { Published } \\
\text { subscales } \\
\text { PD }\end{array}$} & \multirow{2}{*}{\multicolumn{2}{|c|}{ Scale items }} & \multicolumn{3}{|c|}{$\begin{array}{l}\text { ANALYSIS OF SAMPLE I } \\
\text { FACTORS }\end{array}$} & \multicolumn{4}{|c|}{$\begin{array}{l}\text { ANALYSIS OF SAMPLE II } \\
\text { FACTORS }\end{array}$} \\
\hline & & & $\boldsymbol{A}$ & $B$ & $C$ & $\boldsymbol{A}$ & $B$ & $C$ & $D$ \\
\hline & $\begin{array}{l}\text { 1. Bathin } \\
\text { 2. Walkir } \\
\text { 3. Incont } \\
\text { 4. Bedbo } \\
\text { 5. Confus } \\
\text { 6. Appea }\end{array}$ & $\begin{array}{l}\text { Dressing } \\
\text { ence } \\
\text { nd } \\
\text { on } \\
\text { ance }\end{array}$ & $\begin{array}{l}0.77 \\
0.65 \\
0.43 \\
0.19 \\
0.30 \\
0.32\end{array}$ & $\begin{array}{c}0.24 \\
-0.004 \\
0.42 \\
0.14 \\
0.66 \\
0.55\end{array}$ & $\begin{array}{l}0.06 \\
0.02 \\
0.18 \\
0 \cdot 16 \\
0 \cdot 24 \\
0.31\end{array}$ & $\begin{array}{l}0.76 \\
0.69 \\
0.49 \\
0.09 \\
0.27 \\
0.37\end{array}$ & $\begin{array}{r}0.19 \\
-0.06 \\
0.35 \\
0.12 \\
0.67 \\
0.53\end{array}$ & $\begin{array}{l}0.12 \\
0.0003 \\
0.17 \\
0.20 \\
0.36 \\
0.36\end{array}$ & $\begin{array}{r}0.13 \\
-0.03 \\
-0.02 \\
0.04 \\
0.05 \\
0.04\end{array}$ \\
\hline AP & $\begin{array}{r}\text { 7. Superv } \\
\text { 8. Helps } \\
\text { 9. Activit } \\
\text { 10. Sociab } \\
\text { 11. Co-op }\end{array}$ & $\begin{array}{l}\text { sion outside home } \\
\text { n home } \\
\text { es } \\
\text { ity } \\
\text { ration }\end{array}$ & $\begin{array}{l}0.65 \\
0.51 \\
0.57 \\
0.31 \\
0.27\end{array}$ & $\begin{array}{l}.0 .26 \\
0.14 \\
0.34 \\
0.48 \\
0.41\end{array}$ & $\begin{array}{l}0.09 \\
0.11 \\
0.06 \\
0.41 \\
0.41\end{array}$ & $\begin{array}{l}0.64 \\
0.50 \\
0.44 \\
0.20 \\
0.17\end{array}$ & $\begin{array}{l}0.25 \\
0.05 \\
0.25 \\
0.40 \\
0.22\end{array}$ & $\begin{array}{l}0.18 \\
0.04 \\
0.07 \\
0.30 \\
0.32\end{array}$ & $\begin{array}{l}0.08 \\
0 \cdot 20 \\
0.32 \\
0.55 \\
0.64\end{array}$ \\
\hline CD & $\begin{array}{l}\text { 12. Compr } \\
\text { 13. Comm }\end{array}$ & $\begin{array}{l}\text { ehension } \\
\text { anication }\end{array}$ & $\begin{array}{l}0 \cdot 14 \\
0 \cdot 16\end{array}$ & $\begin{array}{l}0.80 \\
0.69\end{array}$ & $\begin{array}{l}0 \cdot 16 \\
0 \cdot 11\end{array}$ & $\begin{array}{l}0 \cdot 10 \\
0 \cdot 10\end{array}$ & $\begin{array}{l}0.76 \\
0.72\end{array}$ & $\begin{array}{l}0.18 \\
0.08\end{array}$ & $\begin{array}{l}0.24 \\
0.26\end{array}$ \\
\hline SD & $\begin{array}{l}\text { 14. Object } \\
\text { 15. Object } \\
\text { 16. Accus } \\
\text { 17. Hoard } \\
\text { 18. Sleep }\end{array}$ & $\begin{array}{l}\text { onable (day) } \\
\text { onable (night) } \\
\text { tions } \\
\text { useless items } \\
\text { attern }\end{array}$ & $\begin{array}{r}-0.02 \\
0.11 \\
0.11 \\
0.02 \\
0.26\end{array}$ & $\begin{array}{l}0.06 \\
0.21 \\
0.08 \\
0.21 \\
0.28\end{array}$ & $\begin{array}{l}0.84 \\
0.62 \\
0.59 \\
0.37 \\
0.28\end{array}$ & $\begin{array}{l}0.01 \\
0.08 \\
0.06 \\
0.04 \\
0.24\end{array}$ & $\begin{array}{r}-0.02 \\
0.14 \\
0.11 \\
0.24 \\
0.21\end{array}$ & $\begin{array}{l}0.75 \\
0.67 \\
0.57 \\
0.38 \\
0.30\end{array}$ & $\begin{array}{l}0.17 \\
0.17 \\
0.08 \\
0.0006 \\
0.06\end{array}$ \\
\hline
\end{tabular}

Table 2 Eigen values

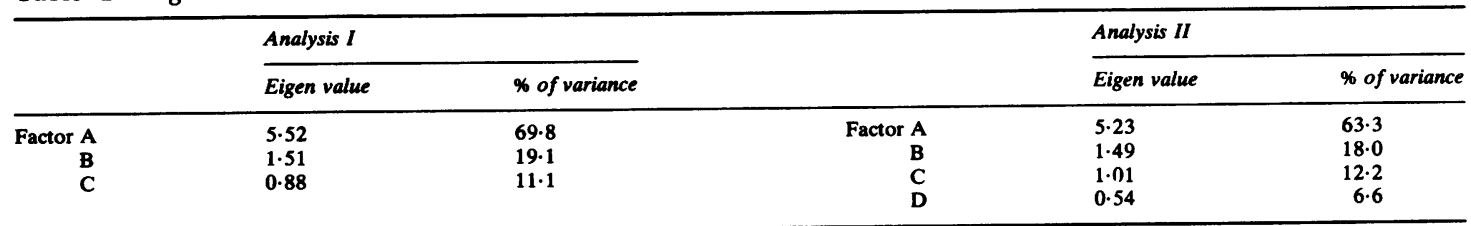




\section{Discussion}

The results fail to support the dimensions of disability suggested in the published scale. A factor corresponding to the 'apathy' subscale fails to appear in either analysis, its items being distributed among the other factors. The first of the two factors which appear stable in both analyses (factor A) appears to correspond to 'physical impairment', and is closely similar to the physical disability scale. The second stable factor (factor B) combines items from several scales but might best be termed 'mental impairment'. Its loadings of confusion, disordered appearance, language difficulties, and general social problems suggest that it is reflecting disability associated with intellectual loss.

A third factor may also be considered, which, although it has a low eigen value in analysis I, does appear in both analyses. This would seem to be measuring 'social impairment', as it is composed of items relating to objectionable behaviour and most closely resembles the social disturbance subscale.

Certain items, notably 'being bedbound' are not clearly related to any others in the scale. Clinical experience suggests that this and certain other items are at least as much a function of the institution as of the level of disability. The emphasis placed on maintaining mobility and the availability of staff to help move patients may, for example, have a significant influence on the rating, such as 'being bedbound'. This analysis can be seen as complementing the data comparing residents of homes with psychogeriatric inpatients. ${ }^{10}$ Those data suggested that some items on the scale (those relating to co-operation, objectionable behaviour during the day, and the hoarding of meaningless items) failed to differentiate the two groups.

In conclusion, it is important to stress the dependence of the results on the subject population. The data reported here do not give information on the dimensions of disability among other groups, particularly hospital inpatients. However, they do indicate that future work in this area must not assume a transferable factorial structure and that consideration should be given to the use of different subscale scores from those currently assumed to be valid.

\section{References}

${ }^{1}$ Gilleard CJ, Pattie AH. The Stockton Geriatric Rating Scale: a shortened version with British normative data. Br J Psychiatry 1977; 131: 90-4.

Alteration to Shortened Stockton Rating Scale. Original item 1:

When bathing or dressing, he/she requiresno assistance some assistance maximum assistance

Replaced by:

1. When bathing he/she requires-

$$
\begin{aligned}
& \text { no assistance } \\
& \text { some assistance } \\
& \text { maximum assistance }
\end{aligned}
$$

2. When dressing he/she requires-

no assistance some assistance maximum assistance

We thank Rita Harris for her invaluable assistance in collecting the data, Dr. N. Vetter, the Research Team for the Elderly, and the Department of Medical Statistics, Welsh National School of Medicine for their full co-operation during the survey.

Reprints from Mr. T. C. Twining, Senior Clinical Psychologist, Whitchurch Hospital, Whitchurch, Cardiff CF4 7XB. 